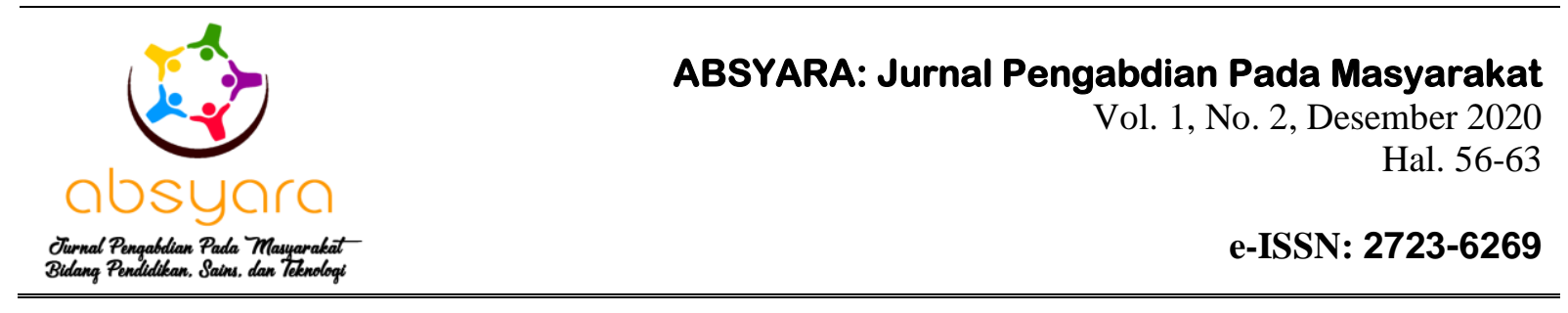

\title{
In House Training (IHT) dalam penyusunan karya tulis ilmiah
}

\author{
Hodiyanto*1, Al Ashadi Alimin ${ }^{2}$, \\ 1"hodiyanto@ikippgriptk.ac.id, ${ }^{2}$ dj_ashadi@ yahoo.co.id \\ ${ }^{1}$ Pendidikan Matematika, IKIP PGRI Pontianak \\ ${ }^{2}$ Pendidikan Bahasa dan Sastra Indonesia, IKIP PGRI Pontianak
}

Received: 4 November 2020

Accepted: 4 Desember 2020 Online Published: 31 Desember 2020

DOI: 10.29408/ab.v1i2.2710

URL: http://dx.doi.org/10.29408/ab.v1i2.2710

\begin{abstract}
Abstrak: Salah satu persyaratan dalam pengajuan kenaikan pangkat guru adalah publikasi karya tulis ilmiah. Akan tetapi berdasarkan hasil wawancara, banyak guru yang mengalami kesulitan dalam menyusun karya ilmiah. Oleh karena itu, melalui Program Kemitraan Masyarakat Stimulus (PKMS) ini dapat membantu guru dalam penyusunan karya tulis ilmiah melalui In House Training (IHT). Program pengabdian pada masyarkat ini bertujuan untuk: 1) meningkatkan pengetahuan guru dalam penyusunan proposal, laporan, dan artikel karya tulis ilmiah, khususnya Penelitian Tindakan Kelas (PTK), 2) mengetahui respon peserta pelatihan. Metode yang digunakan dalam kegiatan ini berupa workshop, pelatihan, seminar, pendampingan atau bimbingan, seminar proposal, dan seminar hasil. Sedangkan untuk mengetahui ketercapaian hasil kegiatan adalah melalui tes mengenai karya tulis ilmiah dan angket kuesioner respon peserta pelatihan. Hasil kegiatan menunjukkan: 1) peningkatan pengetahuan guru peserta pelatihan dalam penyusunan proposal, laporan, dan artikel karya tulis ilmiah, 2) tingkat kepuasan peserta sebesar $88 \%$ yang artinya peserta sangat puas dalam mengikuti kegiatan ini.
\end{abstract}

Kata kunci: In House Training; Karya Tulis Ilmiah; Penelitian Tindakan Kelas (PTK)

\begin{abstract}
One of the requirements in applying for teacher promotion is the publication of a scientific article. However, based on the results of interviews, many teachers have difficulty compiling scientific papers. Therefore, through the Community Stimulus Partnership Program (CSPP), it can help teachers prepare scientific papers through In House Training (IHT). This community service program aims to: 1) increase the knowledge of teachers in the preparation of proposals, reports, and writing scientific articles, especially Classroom Action Research $(C A R), 2)$ determine the responses of training participants. The method used in this activity is workshops, training, seminars, mentoring, proposals seminars, and research results seminars. Meanwhile, determining the achievement of the activity results is through tests about the publication of a scientific article and a questionnaire on training participants' responses. The activity results showed: 1) increased knowledge of teachers in preparing proposals, reports, and scientific writing articles, 2) the level of participant satisfaction was $88 \%$, which means that participants were delighted with this activity.
\end{abstract}

Keyword: Classroom Action Research; In House Training; Scientific Writing

\section{PENDAHULUAN}

Upaya meningkatkan profesionalisme guru di Indonesia terus menerus dilakukan dengan kebijakan-kebijakan perubahan yang disesuaikan dengan perkembangan ilmu pengetahuan dan perkembangan teknologi menuju masyarakat Indonesia yang bermartabat. Salah satu yang menjadi orientasi perubahan yang dilakukan pemerintah dalam hal ini adalah, tentang peningkatan mutu pendidikan di Indonesia yang berkarakter dan bermartabat sehingga diharapkan mampu membentuk manusia Indonesia yang berkarakter dan bermatarbat sebagai 
generasi penerus bangsa.

Pemerintah telah berupaya keras untuk meningkatkan mutu pendidikan di Indonesia, salah satunya adalah tentang kebijakan sertifikasi bagi guru di seluruh Indonesia. Kebijakan yang dicetuskan dalam Undang-Undang No. 14 tahun 2005 tentang Guru dan Dosen ini mengamanatkan bahwa pentingnya peningkatan mutu pendidikan di Indonesia, sehingga mampu bersaing dengan Negara-negara berkembang lainnya. Kebijakan sertifikasi guru dan dosen ini tentunya dapat membawa dampak bagi peningkatan mutu pendidikan di Indonesia. Oleh karena itu, harapan pemerintah yang tertuang dalam setiap kebijakan terhadap guru dan dosen juga semakin ketat sehingga ada keseimbangan antara peningkatan kesejahteraan dan kualitas pelayanan pendidikan masyarakat pada umumnya. Terkait dengan kebijakan itu pemerintah mengharapkan pula ada peningkatan profesionalisme guru dalam hal penelitian yang selanjutnya dapat dipublikasikan secara ilmiah baik dalam bentuk laporan penelitian maupun dalam bentuk jurnal ilmiah hasil penelitian. Hal ini tertuang dalam peraturan Menteri Pendidikan Nasional (Permendiknas) Nomor 35 tahun 2010 Tentang Petunjuk Teknis Pelaksanaan kenaikan pangkat Guru dan Angka Kreditnya dan Peraturan Bersama Mendiknas dan Kepala BKN Nomor 03/V/PB/2010 dan Nomor 14 Tahun 2010 tanggal 6 Mei 2010 tentang Petunjuk Pelaksanaan Jabatan Fungsional Guru dan Angka Kreditnya.

Selain itu, adanya sertifikasi guru juga diharapkan mampu memberikan pengembangan terhadap profesionalisme guru dalam membuat karya tulis ilmiah baik karya ilmiah penelitian maupun karya ilmiah non penelitian. Persoalan karya tulis ilmiah ini merupakan masalah bagi hampir seluruh guru di Indonesia tanpa terkecuali guru yang ada di Kalimantan Barat. Persoalan kenaikan pangkat guru semakin diperketat, yang turut menjadikan guru di Kalimantan Barat khususnya di SDN 17 Pontianak Kota menjadi suatu persoalan yang memerlukan pemecahan secara serius bagi kalangan baik LPTK maupun Dinas Pendidikan terkait dalam pengembangan karya akademik khususnya karya tulis ilmiah ini.

Berdasarkan hasil observasi dan wawancara dengan kepala sekolah Sekolah Dasar Negeri 17 Pontianak Kota masih banyak guru-guru yang tidak bisa mengajukan dupak untuk kenaikan pangkat karena masih lemahnya guru-guru dalam penelitian dan penyusunan karya tulis ilmiah. Pada gambar 1 adalah bukti wawancara dengan Kepala Sekolah Ibu Nuraini, S.Pd dan salah satu guru di SDN 17 Pontianak Kota Bapak Masdi, S.Pd. Mayoritas guru-guru di SD Negeri 17 Pontianak hanya sampai di IV A. Dari hasil wawancara dengan Kepsek bahwa kenaikan IV A ini diperoleh karena kenaikan pangkat secara berkala sebelum diberlakukannya Permenpan No 16 Tahun 2009 Tentang Jabatan Fungsional Guru dan Angka Kreditnya dan Permendiknas No 14 Tahun 2010 Tentang Petunjuk Teknis Pelaksanaan Jabatan Fungsional Guru dan Angka Kreditnya.

Berdasarkan fenomena yang ditemukan atau persoalan yang dialami oleh para guru di SDN 17 Pontianak adalah terhambatnya kenaikan pangkat guru golongan IV/a dan III/d dikarenakan syarat karya tulis ilmiah ini, ditambah lagi dengan kebijakan baru bahwa untuk kenaikan pangkat golongan dari III/b dan seterusnya sudah mensyaratkan karya tulis ilmiah yang dipublikasikan. Persoalan ini menjadi lebih rumit dan menjadi sumber keterlambatan dalam meningkatkan jabatan fungsional guru. Kinerja profesional dapat diukur dengan kenaikan pangkat jabatan guru secara berkala. Oleh sebab itu, kegiatan Program Kegiatan Masyarakat Stimulus (PKMS) perlu dilakukan untuk mengatasi persoalan yang dialami guru khususnya guru di SDN 17 Pontianak Kota. 
Untuk mengatasi permasalah kesulitan guru dalam menyusun karya tulis imiah khususnya penyusuna PTK maka dalam PKMS ini tim akan melakukan kegiatan in house training (IHT) kepada guru-guru SDN 17 Pontianak Kota dalam penyusunan karya tulis ilmiah. Kegiatan IHT merupakan program pelatihan yang diselenggarakan di tempat sendiri, sebagai upaya untukmeningkatkan kompetensi guru, dalam menjalankan pekerjaannya dengan mengoptimalkan potensi-potensi yang ada (Sujoko, 2012). Dari pengertian ini maka IHT adalah adalah pelatihan sumber daya manusia (SDM) yang kegiatannya berdasarkan permintaan oleh institusi klien, sehingga biasanya semua peserta berasal dari satu instansi yang sama. Kegiatan/pelatihan SDM dilaksanakan pada satu institusi saja maka materi dalam kegiatan IHT disesuaikan dengan kebutuhan dari SDM institusi tersebut. IHT adalah salah satu cara yang dapat dilakukan untuk mengembangkan profesionalisme guru (Baharuddin \& Kanada, 2017).

Macam-macam kegiatan IHT: (1) peer teaching, (2) pengamatan video pembelajaran, (3) diklat, (4) workshop, (5) seminar, (6) diskusi terkait pendidikan (7) pembuatan alat peraga, (8) penelitian, (9) penulisan buku/bahan ajar, (10) pembuatan media pembelajaran, (11) pembuatan karya teknologi/ karya seni (Kasmad, 2015). Adapun pelaksanaan IHT dalam Program Kemitraan Masyarakat Stimulus (PKMS) adalah berupa kegiatan pelatihan, diskusi, workshop, dan pembimbingan/pendampingan. Keuntungan dan manfaat dari IHT meliputi: (1) tidak perlu membayar biaya perjalanan karena karena pelaksanaan di temapat peserta kerja sehingga pembiayaan lebih murah. (2) pelatihan akan lebih fakus dan nyaman karena dilaksanakan di tempat para perserta pelatihan, sehingga contoh-contoh bisa diambil langsung dari tempat pelatihan (Drayto, 2017). Berdasarkan hasil IBM Dharmawan, Ramona, \& Rupiasih (2016) bahwa kemampuan guru dalam menyusun karya tulis ilmiah tergolong efektif setelah diberikan IHT. Wardani, dkk. (2019) juga menggunakan IHT dalam pelaksanaan penelitian tindakan kelas untuk meningkatkan profesionalisme guru di Kabupaten Pringsewu. Melalui kegiatan IHT dalam PKMS ini guru-guru ditargetkan dapat memahami jenis-jenis karya tulis ilmiah dan mampu menyusun karya tulis ilmiah (PTK) dan membuat artikel ilmiah. Selain itu, para peserta juga diharapkan mampu untuk submit artikel ilmiah minimal ke jurnal cetak yang ada di Kalimantan Barat.

\section{METODE PELAKSANAAN}

\section{Waktu dan tempat}

Pelaksanaan pelatihan melalui IHT ini dilaksanakan di SDN 17 Pontianak Jalan 1. Putri Candramidi, Sungai Bangkong, Kec. Pontianak Kota, Kota Pontianak Prov. Kalimantan Barat. Pelaksanaan PKMS ini dimulai dari bulan April 2019 sampai September 2019.

\section{Prosedur pelaksanaan}

Melalui kegiatan IHT ini diharapkan guru-guru mampu menyusun dan membuat PTK sampai ke draf artikel ilmiah. Adapaun langkah dalam IHT ini mencakup perencaan, pelaksanaan, dan evaluasi.

1. Perencaan

Dalam kegiatan IHT ini diperlukan adanya perencaan terkait pelaksanaan dan pembiyaan yang diperlukan. Keberhasilan dan suksesnya kegiatan tentu harus melalui perencaan yang bagus. Dalam kegiatan IHT yang perlu dibuat adalah mambuat tujuan 
IHT; menentukan metode IHT, peserta, materi, waktu dan tempat, bahan yang diperlukan dalam pelatihan, model evaluasi, dan pembiayaan yang dibutuhkan.

2. Pelaksanaan

Pelaksanaan merupakan implementasi dari perencanaan. Dalam pelaksanaan dibagi lagi ke dalam dua tahapan. Tahap persiapan dan tahap pelaksanaan. Tahap persiapan yang perlu dilakukan dalam PKMS ini adalah persiapan bahan seperti materi, jadwal pertemuan, instrumen, dan evaluasi). Pada tahap persiapan tim PKMS melakukan koordinasi terhadap pihak sekolah dalam rangka persipan pelaksanaan kegiatan IHT. Pelaksanaan IHT yang akan dilakukan dalam PKMS ini terdiri dari beberapa tahap dan dibantu dua orang mahasiswa. Kegiatan tersebut diawali dengan workshop KTI, pendampingan penyusunan proposal, seminar proposal, pendampingan penyusunan laporan penelitian, pelatihan penulisan artikel ilmiah, dan seminar hasil penelitian.

3. Evaluasi

Program Kemitraan Masyarakat Stimulus (PKMS) melalui peningkatan kapasitas guru dalam penyusunan karya tulis ilmiah lebih khusus Penelitian Tindakan Kelas (PTK) yang melibatkan mahasiswa, tentu dievaluasi mengenai:

a. Hasil kerja laporan penelitian tindakan kelas.

b. Tanggapan guru sebagai peserta PKMS terhadap pelaksanaan kegiatan IHT yang berupa seminar, workshop, pendampingan yang dibuat.

c. Tanggapan guru terhadap apa yang dipahami setelah mengikuti PKMS.

d. Tanggapan Kepala Sekolah terkait kegiatan PKMS.

Adapun yang terlibat dalam kegiatan PKMS ini adalah tim PKMS dua orang, dua orang mahasiswa dan guru-guru di SD Negeri 17 Pontianak.

Tabel 1. Tim PKMS

\begin{tabular}{llcc}
\hline No & \multicolumn{1}{c}{ Nama } & Jabatan dalam PKMS & Pekerjaan \\
\hline 1. & Hodiyanto, M.Pd & Ketua & Dosen \\
2. & Al Ashadi Alimin, M.Pd & Anggota & Dosen \\
3. & Syarif Restian Mandala Putra & Anggota & Mahasiswa \\
4. & Tri Jayanti & Anggota & Mahasiswa \\
\hline
\end{tabular}

Tabel 2. Data Guru-Guru SDN 17 Pontianak

\begin{tabular}{clccccc}
\hline No & \multicolumn{1}{c}{ Nama } & NIK & $\begin{array}{c}\text { Tanggal } \\
\text { Lahir }\end{array}$ & $\begin{array}{c}\text { Golongan } \\
\text { Terakhir }\end{array}$ & $\begin{array}{c}\text { TMT } \\
\text { Golongan }\end{array}$ & $\begin{array}{c}\text { TMT di } \\
\text { Sekolah }\end{array}$ \\
\hline 1 & Aminah & 6171034208770003 & $1977-08-02$ & III A & $2011-10-01$ & $2006-04-01$ \\
2 & Indra Gunawan & 6171041111720001 & $1972-11-11$ & III A & $2014-08-01$ & $2002-12-01$ \\
3 & Kartini & 6171012306670004 & $1972-11-14$ & III D & $2013-04-01$ & $2013-04-01$ \\
4 & Masda & 6171054801670006 & $1967-01-08$ & III D & $2010-10-01$ & $2006-01-02$ \\
5 & Masdi & 6171052104640006 & $1964-04-21$ & IV A & $2007-10-01$ & $2013-03-11$ \\
6 & Nuraini & 6171046911700001 & $1970-11-29$ & III D & $2014-10-01$ & $2000-03-01$ \\
7 & Nurlaila & 6171035005660013 & $1966-05-10$ & III A & $2014-08-01$ & $2002-01-15$ \\
8 & Puji Kasiani & 6171055007680004 & $1968-07-10$ & IV A & $2010-10-01$ & $2002-12-02$ \\
9 & Riennova & 6171014201820000 & $1982-01-02$ & III B & $2013-04-01$ & $2009-02-01$ \\
10 & Siti Nurhamidah & 6171056909640009 & $1964-09-29$ & IV A & $2006-04-01$ & $2005-07-01$ \\
11 & U. Novika & 6101055711860000 & $1986-11-17$ & III A & $2015-10-01$ & $2010-01-01$ \\
\hline
\end{tabular}


Berdasarkan tabel 1 dan tabel 2 maka jumlah peserta yang terlibat dalam PKMS ini berjumlah 11 orang, sedangkan tim PKMS terdiri dari 2 orang dan dibantu oleh 2 orang mahasiswa. Alat pengumpulan data yang digunakan dalam kegiatan PKMS ini berupa tes pemahaman PTK, dan angket respon kegiatan PKMS. Tes pemahaman PTK ini diberikan sebelum dan setelah kegiatan PKMS, sedangkan respon diberikan setelah kegiatan PKMS selesai.

\section{HASIL DAN PEMBAHASAN}

\section{Hasil}

\section{Respon Peserta dalam Kegiatan PKMS}

Pengabdian ini dilaksanakan selama kurang lebih 6 bulan, secara umum pelaksanaan PKMS yang dilakukan menunjukkan tingkat kepuasan peserta sebesar 88\%. Berdasarkan hasil angket kepuasan yang diberikan kepada peserta menunjukkan bahwa 94\% peserta berpendapat bahwa tim PKMS ahli dibidangnya, 90\% materi yang disampaikan bermanfaat, 86\% materi yang disampaikan sesuai denga tema PKMS, 87\% pelaksanaan PKMS sesuai dengan harapan peserta, dan $84 \%$ fasilitas yang diberikan pada saat kegiatan PKMS sudah sesuai. Adapun capaian yang sudah dihasilkan dalam kegiatan PKMS ini adalah peningkatan pengetahuan guru mengenai penelitian tindakan kelas (PTK), laporan hasil PTK peserta, artikel ilmiah hasil PTK peserta, draf artikel ilmiah pengabdian dan narasi kegiatan yang sudah terbit di tribun Pontianak online, dan video kegiatan yang sudah diupload.

\section{Peningkatan Pengetahuan Karya Tulis Ilmiah}

Sebelum PKMS ini dilakukan, tim PKMS memberikan tes awal kepada peserta untuk mengetahu pengetahuan awal peserta dalam penyusunan karya tulis ilmiah khususnya penelitian tindakan kelas (PTK). Di bawah ini akan ditampilkan hasil pengetahuan peserta sebelum dan sesudah dilakukan in house training (IHT) dalam penyusunan karya tulis ilmiah khsusunya PTK.

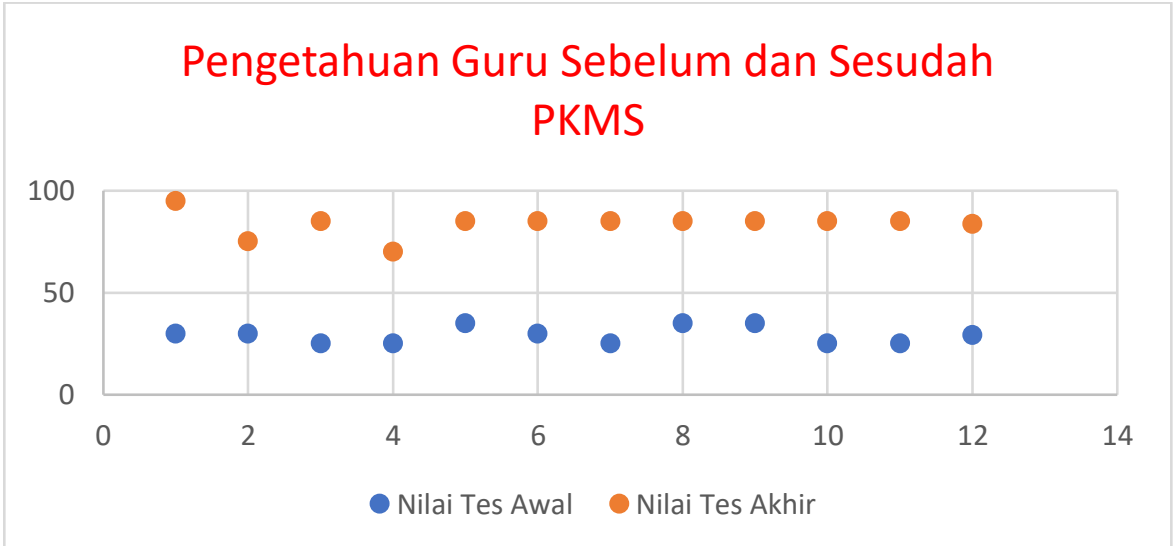

Gambar 1. Grafik Pengetahuan Guru Sebelum dan Sesudah Kegiatan PKMS

Selain itu, berdasarkan hasil tes pengetahuan peserta mengenai karya tulis ilmiah khususnya penelitian tindakan kelas (PTK) diperoleh bahwa pengetahuan guru sebelum diberikan IHT masih tergolong rendah dengan rerata 29,1, tetapi setelah diberikan IHT pengetahuan guru mengenai PTK mengalami peningkatan dengan rerata 83,6. Hal ini menunjukkan bahwa IHT memberikan pengaruh dan kontribusi yang positif terhadap peningkatan pengetahuan guru dalam penyusunan karya tulis ilmiah khususnya penelitian 
tindakan kelas (PTK). Kegiatan PKMS ini dimulai dari koordinasi dengan pihak sekolah mitra SDN 17 Pontianak Kota, Workshop KTI, pendampingan dan bimbingan KTI, dan pada saat laporan kemajuan ini dibuat, kegiatan PKMS sampai pada seminar proposal.
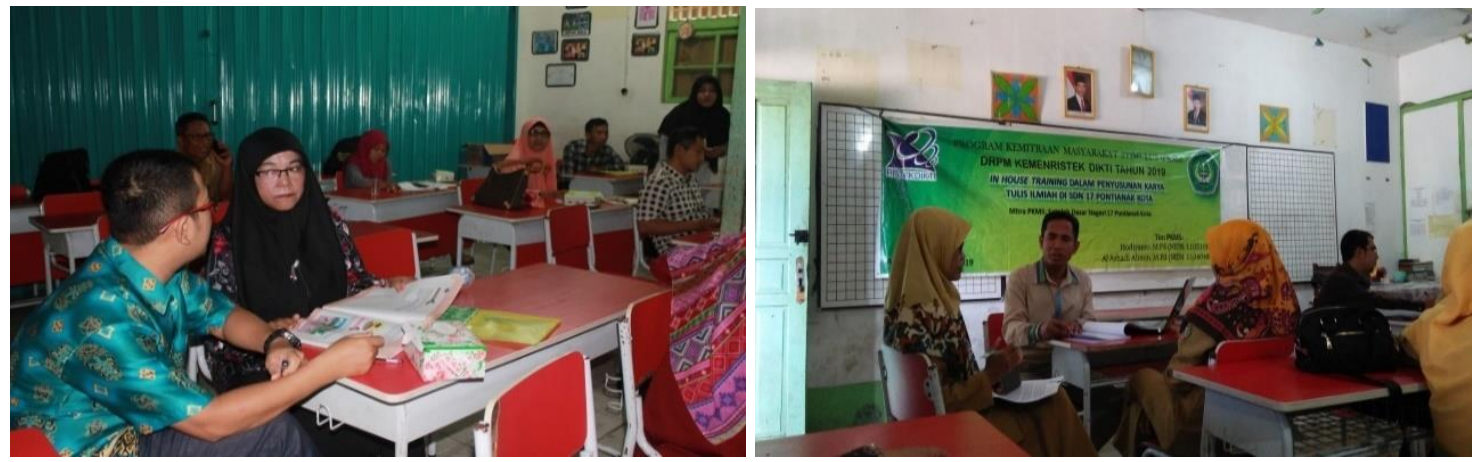

Gambar 2. Kegiatan Workshop dan Pendampingan dan Bimbingan Proposal PTK
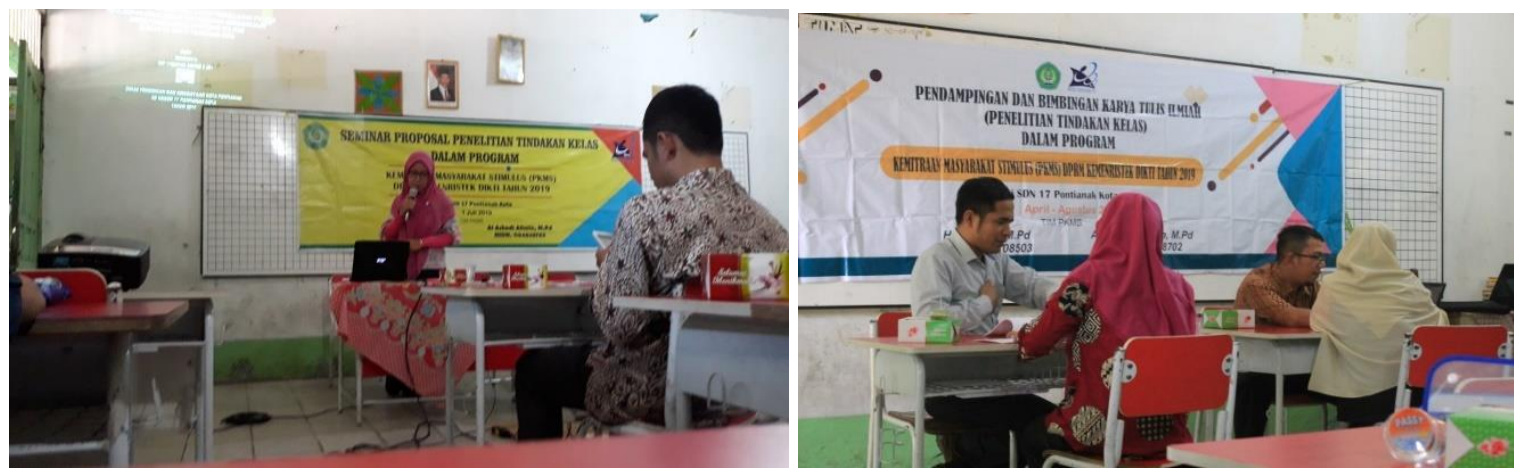

Gambar 3. Seminar Proposal dan Pendampingan Laporan Hasil PTK

Pada gambar 3 menunjukkan aktivitas dalam kegiatan PKMS yang berupa workshop KTI dan dilanjutkan dengan pendampingan penyusunan proposal PTK. Jadi, sebelum peserta diminta untuk membuat proposal, tim PKMS memberikan workshop dulu mengenai cara penyesunan proposal PTK. Setelah proposal sudah sudah selesai maka dilanjutkan dengan seminar proposal dan pendampingan penyusunan laporan hasil penelitian seperti tampak pada gambar 4. Selanjutnya, pada gambar 5 peserta dilatih untuk menulis artikel ilmiah dari laporan hasil penelitian tersebut dan diakhiri dengan seminar hasil penelitian. Pada saat pendampingan, tim PKMS selalu memberikan motivasi dan membantu peserta jika mengalami permsalahan dalam penyusunan proposal, laporan maupun artikel ilmiah.
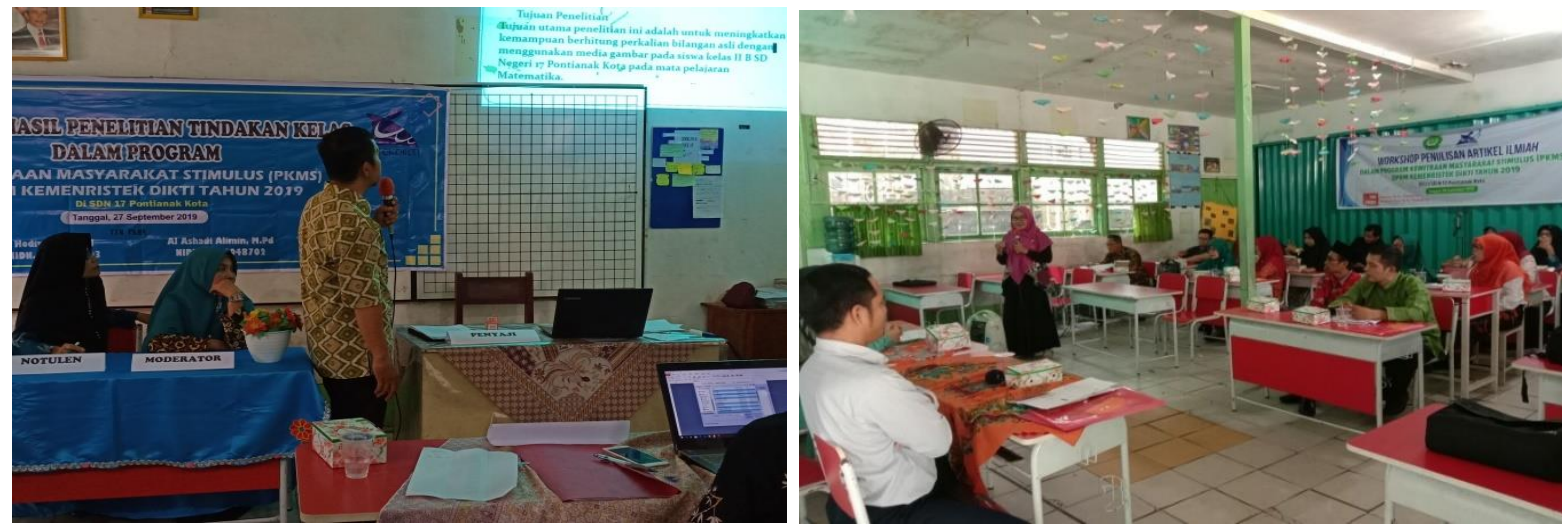

Gambar 4. Pelatihan Penulisan Artikel Ilmiah dan Seminar Hasil PTK 


\section{Pembahasan}

Dalam kegiatan ini diperoleh laporan hasil PTK peserta yang bisa diajukan untuk pengajuan angka kredit. Ada 7 laporan hasil PTK peserta yang sudah diterima oleh tim PKMS, sedangkan laporan peserta yang lain masih tahap revisi. Selain laporan hasil penelitian tindakan kelas (PTK), peserta juga membut artikel ilmiah dari hasil PTK. Artikel peserta saat ini sudah disubmitkan dan masih dalam proses in review pada Jurnal Penelitian Guru-Guru Ketapang yang terdiri dari: Matan Tanjung Pura Kayong (PPKn), Kecubong Kayong (IPA), Cerdas Kayong (MTK), Ulu Aik Kayong (IPS), dan Mantra Kayong (Bahasa). Hasil ini menunjukkan adanya peningkatan kemampuan guru dalam penyusunan proposal, laporan dan artikel PTK selama mengikuti kegiatan PKMS ini melalui IHT yang berupa pelatihan, workshop, dan pendampingan. Hasil ini sesuai dengan hasil pengabdian yang dilakukan Neneng \& Basuki (2019), Djariyo, dkk. (2011), dan Gunawan, Triwiyanto \& Kusumaningrum (2018) bahwa pelatihan dan pendampingan dapat meningkatkan kemampuan guru dalam penyusunan karya tulis ilmiah.

\section{SIMPULAN}

Pengabdian ini sudah dilakukan sampai seminar proposal. Dari hasil PKMS melalui in house training dapat disimpulkan sebagai berikut: (1) peningkatan pengetahuan guru dalam penyusunan proposal, laporan dan artikel karya tulis ilmiah (KTI) khususnya PTK, (2) pelaksanaan PKMS yang dilakukan menunjukkan tingkat kepuasan peserta sebesar $88 \%$.

\section{PERNYATAAN PENULIS}

Pernyataan tentang bahwa artikel yang dibuat belum pernah dipublish pada jurnal yang lain.

\section{UCAPAN TERIMA KASIH}

Terima kasih kami sampaikan kepada KEMENRISTEKDIKTI atas dana Hibah PKMS Tahun Anggaran 2019 yang telah diberikan serta IKIP-PGRI Pontianak yang telah menjadi mitra dalam kegiatan penelitian ini.

\section{DAFTAR PUSTAKA}

Baharuddin, B., \& Kanada, R. (2017). Pengembangan Profesionalisme Guru Melalui In House Training. El-Idare: Jurnal Manajemen Pendidikan Islam, 3(2), 1-20.

Dharmawan, K., Ramona, Y., \& Rupiasih, N. N. (2016) Model Pembinaan In-House Training sebagai Upaya Untuk Meningkatkan Kemampuan Guru Dalam Penelitian Dan Penulisan Karya Ilmiah. Jurnal Udayana Mengabdi, 15(2), 74-81.

Djariyo, I. K. I. P., Suliyanto, J., Mudzanatun, I. K. I. P., Reffiane, F., \& Purnamasari, I. (2011). Pelatihan Penulisan Karya Ilmiah Untuk Meningkatkan Keterampilan Menulis Bagi Guru Sekolah Dasar Di Kota Semarang. E-Dimas: Jurnal Pengabdian kepada Masyarakat, 2(1), 13-19.

Drayton, S. (2017). The Advantages and Disadvantages of In-House Training.

Gunawan, I., Triwiyanto, T., \& Kusumaningrum, D. E. (2018). Pendampingan penulisan artikel ilmiah bagi para guru sekolah menengah pertama. Abdimas Pedagogi: Jurnal Ilmiah Pengabdian kepada Masyarakat, 1(2), 128-135. 
Kasmad, K. (2015). Upaya Meningkatkan Kualitas Pembelajaran Tematik Terpadu Melalui Kegiatan in House Training (Iht) Bagi Guru Kelas I SD. Jurnal Konseling Gusjigang, $1(2)$.

Neneng, L., \& Basuki, B. (2019). Peningkatan Kemampuan dan Keterampilan Guru Biologi Menulis Karya Ilmiah melalui Pelatihan dan Pendampingan. Jurnal Pendidikan, 20(1), 25-34.

Permendiknas. (2010). Peraturan Bersama Mendiknas dan Kepala BKN Nomor 03/V/PB/2010 dan Nomor 14 Tahun 2010 tanggal 6 Mei 2010 tentang Petunjuk Pelaksanaan Jabatan Fungsional Guru dan Angka Kreditnya.

Permendiknas. (2010). Peraturan Menteri Pendidikan Nasional Nomor 35 tahun 2010 Tentang Petunjuk Teknis Pelaksanaan Jabatan Fungsional Guru dan Angka Kreditnya.

Sujoko, A. (2012). Peningkatan Kemampuan Guru Mata Pelajaran melalui In-House Training. Jurnal Pendidikan Penabur, 11(18), 27-39.

Undang-Undang Republik Indonesia Nomor 14 Tahun 2005 Tentang Guru Dan Dosen.

Wardani, W., Karsiwan, K., Purwasih, A., Lisdiana, A., \& Hammer, W. (2019). Pendampingan Pelaksanaan Penelitian Tindakan Kelas Dalam Meningkatkan Profesionalisme Guru Di Kabupaten Pringsewu. DEDIKASI: Jurnal Pengabdian Masyarakat, 1(2), 323-342. 